\title{
A deviáns veszélyeztetettség és az anyai kötődés kapcsolata
}

\author{
Nász Barbara \\ Eszterházy Károly Főiskola, Neveléstudományi Doktori Iskola, PhD-hallgató
}

\begin{abstract}
Kutatásom témája a szülőkhöz való kötődés anyai dimenziójának vizsgálata. Jelen tanulmány egy pilotkutatás eredményeit mutatja be. A kutatásban magas rizikófaktorú deviáns-veszélyeztetett, illetve nem veszélyeztetett fiatalok anyához való kötődésének erösségét vizsgáltam kérdőíves módszerrel.

A tanulmányban a deviáns-veszélyeztetettség kialakulásában felelős lehetséges rizikófaktorok, illetve a veszélyeztetettség megelőzésében hangsúlyos védőfaktorok, valamint a kötődés életkori sajátosságokra vonatkozó jellemzői mellett, a kötődés mint viselkedés és a kötödési variabilitás oksági háttere is bemutatásra kerül. A vizsgálat fókuszában alapvetően a deviáns-veszélyeztetettség és az anyához füződő kapcsolat intenzitása közötti összefüggés feltárása áll.
\end{abstract}

Kulcsszavak: kötődés, anyához való kötődés, deviáns-veszélyeztetett fiatalok, rizikóés védőfaktorok a deviáns-veszélyeztetettségben

Az alábbi tanulmányban egy pilotkutatás eredményei kerülnek bemutatásra, melynek célja a magas rizikófaktorú deviáns-veszélyeztetett és nem veszélyeztetett iskolás- és serdülőkorú fiatalok anyához való kötődésének vizsgálata volt. A kutatás során arra kerestem a választ, hogy van-e kapcsolat a deviáns-veszélyeztetettség és az anyához füződő kapcsolat intenzitása között.

A kötődésvizsgálatokkal kapcsolatban két álláspont jellemző a kutatók körében: a kérdőívvel végzett feltárás, illetve az interjúmódszer. Az általam használt Inventory of Parent and Peer Attachment kérdőív középpontjában a kötődés erősségének mérése áll. A kutatás célja alapvetően a kötődés szorosságának vizsgálata volt, így az IPPA alkalmazása célszerűnek bizonyult. Az interjútechnikák segítségével a kötődés egyéb dimenziói, így maga a biztonságosság is könnyen feltárható, jelen kutatást illetően azonban a mintázatok feltárása irreleváns.

\section{A deviáns viselkedés kialakulása - védőfaktorok és rizikófaktorok}

A különböző társadalmak maguk építik föl értékrendszereiket, tehát saját maguk határozzák meg, hogy mi számít elfogadottnak az adott kultúrában. Vannak olyan magatartásformák, viselkedésminták, melyeket bizonyos társadalmak elfogadottnak találnak, míg mások már devianciának minősítenek. A globalizációnak és a nagyléptékű változásoknak köszönhetően a normarendszerek is állandó változásban vannak, így lehetséges, hogy egy adott korban és kultúrában deviánsnak minősített magatartásforma egy másik kultúrában és korban nem számít devianciának.

A normaszegő magatartás kialakulásában számos tényező játszik közre. A biológiai és a genetikai összetevők mellett a pszichikai tényezők is rizikófaktornak minősülnek, melyek előidézhetik a deviáns viselkedés kialakulását.

A pszichikai tényezőket illetően, kiemelkedő fontosságú a korai anya-gyermek kapcsolat sérülése. A gyermekkori szociális kötődés hatásai felnőttkorban is jelen vannak. A tolerancia, az empátiás készség, mások iránt érzett szolidaritás alapja lehet a megfelelő szociális kötődés, Bowlby szerint. A problémamegoldó képesség, valamint a 
stresszkezelésben mutatott jártasság is összefüggésben van a korai anya-gyermek kapcsolat kiegyensúlyozottságával, s ezek a képességek csökkenthetik a felnőttkori pszichopatológiai jelenségek kialakulásának valószínúségét (Bowlby, 1980 idézi Pikó, 2011).

Oki tényezőként gyakran jelenik meg a gyerekkori szocializációs zavar. A deviáns viselkedések esetében gyakorta előfordul valamilyen kommunikációs deficit, így például az önkifejezés problémája vagy a társas kapcsolatteremtés zavara. Ezek a hiányosságok a szocializációs készségek fejlődési zavaraiból eredeztethetőek. Természetesen az egészségkárosító családszerkezeti és a nevelési tényezők szerepe is meghatározó. A deviáns magatartás családon belüli halmozódása elsősorban nem genetikai okokra vezethető vissza, hanem a mintakövetés, a hosszadalmas depriváció, illetve a kóros magatartási reakciók átvételére, ezt pedig szociogenetikus transzmiszsziónak nevezzük (Pikó, 2011).

A deviancia kialakulásának oki hátterében tehát többféle indok is húzódhat. A különböző okok mellett azonban rendkívül fontos tényező az, hogy az adott viselkedést a környezet deviánsnak minősítse. Ehhez pedig szükséges a társadalmi és környezeti kontroll, az egyértelmű normák jelenléte, amihez képest eltérő az adott viselkedés.

A család szerepe kiemelkedően fontos a deviancia kialakulásában és megelőzésében, mert a család a társadalmi együttélés legkisebb egysége, az elsődleges szocializációs tér. A család által képviselt és közvetített értékek átörökítődnek a fiatalabb generációk tagjaira. A család optimális esetben egy érzelmi közösség, s ilyen formában védőhálóként van jelen az ember életében.

Ma Magyarországon a gyermekek közel egynegyede él abszolút szegénységben, s mivel a szegénység reprodukálódik, így a következő generációk is nagy valószínűséggel kényszerülnek hasonló helyzetbe (Eurostat, 2014). Ez a folyamat egyet jelent a tartós leszakadással, ami kiváló táptalajként szolgálhat az eltérő irányú szocializációnak, illetve a különböző devianciák kialakulásának. Természetesen a gyermekés fiatalkorúak veszélyeztetettsége nemcsak a család anyagi körülményeire vezethető vissza, hanem más, a családban lévő különféle káros hatások jelenlétéből is fakadhat (Kisida, 1999). Ilyen káros hatások lehetnek a szülöi deviancia különböző megnyilvánulási formái is.

Amennyiben a család valamilyen oknál fogva nem tölti be funkcióját, vagyis nem nyújt a gyermeknek humán értékeket, akkor a gyermek nem fogja fontosnak érezni a családi köteléket, s máshol fog kötődési pontokat keresni. Ilyen családon kívüli kötödési pontok lehetnek elsősorban a hasonló társadalmi helyzetű kortárs csoportok is (Kisida, 1999). Ezekben az esetekben a család tradicionális funkcióvesztése mellett a védőfaktor szerepe is megszűnik, s a mintakövetés következtében fennálló reprodukciós lehetőségek miatt inkább rizikófaktorként jelenhet meg a gyermek életében.

A családon belül kiemelt fontosságú az anyához füződő viszony, ennek feltárásához pedig a kötődés minőségének megismerése vihet közelebb, így elengedhetetlen kitérni a kötődés elméleti hátterének áttekintésére is.

\section{Ragaszkodás, kötődés és az egyéni különbségek Bowlby szemüvegén keresztül}

Az emberi faj egyedei koraszülöttként jönnek világra, létünk ekkor teljes mértékben anyánktól függ. A csecsemő és az anya vagy gondozó kapcsolata emberi sajátosság, amit egyfelől a lét biztosítása, másrészt a ráutaltság határoz meg. Egy idő után a gyermekben kialakul ennek a kapcsolatnak az érzelmi megfelelője is és az anyához való kapcsolat igénye biztonsági szükségletként jelentkezik. A csecsemőnek hosszú időn 
keresztül az anyja az egyetlen és legfontosabb emberi kapcsolata, ezért ez a kapcsolat feltétele és első mintája az olyan kötődéseknek, amit felcserélhetetlennek élünk meg (Mérei és V. Binét, 1970).

Ezek a feltételek a gyermekben úgynevezett ragaszkodó magatartást aktiválnak. A ragaszkodó viselkedés velünk született viselkedésformák és reakciókészletek öszszessége, amely az anya közelségének megszerzésére irányul (Bowlby, 2009).

Különbséget kell tennünk azonban a ragaszkodó magatartás és a kötődés között. A ragaszkodás az aktív közelségkeresést jelenti és más-más célszemélyekre is irányulhat. A kötődés ezzel szemben egy sokkal mélyebb és szorosabb kapocs. Akkor beszélhetünk kötődésröl, ha a ragaszkodó magatartás egy, a gyermek számára különösen fontos személy felé irányul, és ennek a személynek a közelségét keresi, illetve próbálja ezt a közelséget fenntartani, hogy biztonságban érezze saját magát (Pulay, 2003).

Bowlby egészen más aspektusból közelítette meg a szülő és a gyermek közötti kontaktust, mint korának gondolkodói. A freudi tanok létjogosultságát és alapjait, tehát tulajdonképpen az anya-gyermek kapcsolat analitikus természetét vonta kétségbe. Bowlby, elméletének alátámasztására, kidolgozott egy evolúciós-etológiai modellt, melyben ötvözte az etológia ösztöntanát, Piaget kognitív fejlödéselméletét, illetve az általános rendszerelméletet. Elméletének esszenciális pontja, hogy az anya és gyermeke közötti kötődés kialakulásában nem az éhség-drive redukció a kardinális elem, hanem az érzelmi biztonság, az odafigyelés és a támogatásnyújtás (Bowlby, 2009).

Freud elméletével ellentétben, Bowlby kötődésről alkotott elképzelései a következők: a kötődés önálló - a táplálkozástól teljes mértékben független - motivációs bázissal rendelkezik, ami a törzsfejlődés során a gyermek túlélésének biztosítására alakult ki (Láng, 2012).

Ha a gyermek és gondozója között biztos és kölcsönös érzelmi kapocs alakul ki, ez az állapot segítségként szolgál a gyermeknek fenntartani a biztonságérzetet az egyre gyakoribb és hosszabb elválási időszakokban is. Ez a szakasz addig fejlődik, míg a gyermek gondolkodásának szerves részévé válik a szimbolikus reprezentáció. Bowlby úgy gondolta, hogy a gyerekek szimbolikus képességének fejlődésével a szülő-gyermek kötődés belső munkamodellé, a gondozókkal és másokkal folytatott interakciók mentális normájává válik (Cole, 2006).

A kötődés egy olyan fontos érzelmi kapcsolat, amely hosszú távú és bizonyos személyhez köthető. Ennek hatására a kötődő egyén keresi az adott személlyel való közelséget és feszültséget él át távollétében, illetve biztonságot jelenlétében. $A$ biztonság elért élménye vagy annak hiánya a gondozóval való újabb találkozáskor fogja meghatározni a biztos és a bizonytalan kötődési típusokat.

Fontos tisztázni továbbá, hogy a kötődés és a kötődési viselkedés nem egy és ugyanaz. Egy nyugodt, elégedett gyermek nem feltétlenül produkálja a kötődéses viselkedést, annak ellenére, hogy kötődik gondozójához, mert a kötődési viselkedésrendszer nem lépett müködésbe, elképzelhető, hogy éppen a gondozó megnyugtató jelenlétének következtében. Minden helyzetben változhat, hogy milyen mértékű stresszkeltő inger szükséges a kötődési viselkedésrendszer aktiválódásához (F. Lassú, 2011).

A kötődés két nagy csoportba sorolható minősége alapján: megkülönböztetünk biztos és bizonytalan kötődési mintázatokat. A két különböző típust elsőként Mary Ainsworth, Bowlby egyik munkatársa tárta föl. Az idegen helyzetnek nevezett kísérlet során a csecsemők anyjuk távozására és visszatérésére adott reakcióit vizsgálták (Atkinson, 2005).

Az idegen helyzetben produkált viselkedés alapján Ainsworth az alábbi kötődési kategóriákat különböztette meg: biztonságos kötődés és kétfajta bizonytalan kötődés 
- a szorongó/elkerülő és a szorongó/ambivalens, illetve a zavarodott vagy dezorganizált kötődés, melyek az alábbi jellemzőkkel bírnak:

Biztonságos kötődés. A biztonságosan kötődő gyerekek nem kifejezetten mutatnak kötődési viselkedést, míg biztonságban érzik magukat. Amikor gondozójuk elhagyja a szobát láthatóan nyugtalanok lesznek, szorongani kezdenek, és az idegen nem tudja őket megnyugtatni. A visszatéréskor azonban keresik anyjuk közelségét, könnyen megnyugszanak és visszatérnek a játékhoz (Cole, 2006).

A bizonytalanul kötődő gyerekeket éppen ellentétes érzelmek jellemzik. Az ő esetükben a gondozó válaszkészsége nem volt állandó, így nem alakult ki bennük a bizalom és a biztonságérzet. A gyerek folyamatosan szorong a gondozó elérhetősége miatt, attól fél, hogy el fogja őt hagyni, nem fog ráfigyelni, mikor szüksége lenne rá. A bizonytalanul kötődésnek két nagy csoportja van: a bizonytalan elkerülő és a bizonytalan ellenálló (F. Lassú, 2011).

Szorongó/elkerülő kötődés: A bizonytalan elkerülő gyerekek általában nyugodtan játszanak gondozójuk jelenlétében. Az elválás nem nyugtalanítja őket, ha mégis előfordul ilyesmi az idegenek hatékonyan meg tudják őket nyugtatni. Amikor a gondozó visszatér, a gyerekek közönyt mutatnak, gyakran elfordulnak, elnéznek, egyáltalán nem keresik közelségét (Cole, 2006).

Szorongó/ambivalens kötődés: Ezek a gyerekek már az idegen helyzet kezdetén problematikusan viselkednek. Szorosan a gondozójuk mellett vannak, ennek ellenére ekkor is szorongani látszanak. A távozáskor nagyon feldúltak, de a visszatérés sem tudja őket megnyugtatni. Újra meg újra érintkezést keresnek gondozójukkal, de ellenállnak, mikor az meg akarja őket vigasztalni. A bizonytalan ellenálló gyerekek nem térnek vissza a játékhoz, hanem inkább aggodalmasan figyelik gondozójukat (Cole, 2006).

Zavarodott vagy dezorganizált kötődés: Ebbe a kategóriába tartozó gyerekek zavartnak tűnnek az idegen helyzetben. Nem képesek rendezett módon kezelni a feszültséget. Egyesek hangos sírásba kezdenek, majd megpróbálnak felmászni a gondozójuk ölébe, mások a gondozó felé indulnak, de közben nem néznek rá. Egyes esetekben ezek a gyerekek kábult állapotba kerülhetnek, és nem mozdulnak meg anyjuk jelenlétében (Main és Solomon 1990; Main és Hesse 1990).

\section{A kötődési variabilitás oksági háttere}

A kötődés okának vizsgálatakor elsőként a proximális faktorokat igyekeztek feltárni. Négy nagy pólust különböztetnek meg, amelyek együttesen határozzák meg a csecsemő kötődési minőségét. A négy szegmens a következő: a szülői viselkedés, a gyermek jellemzői, a család befolyása, illetve a kulturális hatások (Cole, 2006).

A család dominanciájáról már korábban is szó esett a deviancia reprodukciója kapcsán. A kötődési különbözőségek kialakulásában is kardinális szerepe van mind a szülök viselkedésének, mind a családnak.

A szülői viselkedést, konkrétan a gondozói szenzitivitást, rendkívül meghatározó faktornak találta Ainsworth és Bell a biztonságos kötődés kialakulásában. Vizsgálataik azt támasztják alá, hogy a gondozó gyors és finom válaszkészsége, illetve alapvetően a gyermek igényeire történő reagálás különösen fontos a biztonságos kötődés eléréséhez (Atkinson, 2011).

A gyermek legfontosabb jellemzője, a kötődés perspektívájából közelítve, a temperamentuma. A szülő és a gyermek közötti interakció összhangja mindkét félen múlik. A csecsemőnek anyai válaszkészségre van szüksége a fejlődéshez, az anyának pedig fogékony csecsemőre, hogy gondozói feladatait tökéletesen elláthassa (Cole, 2006). 
A temperamentum egy velünk született tulajdonság, amihez alkalmazkodni lehet, azonban megváltoztatni különösen nehéz. A temperamentum aspektusából két csoportot különböztetünk meg: könnyü csecsemők és nehéz csecsemők.

A könnyű csecsemők pozitív visszacsatolást jelentenek a gondozónak abból a szempontból, hogy jól végzik gondozói feladataikat. A nehéz csecsemők ellenben negatív visszajelzést jelentenek. A gondozó csalódott, szorongó lehet, amiért - a csecsemő visszajelzései alapján - megfogalmazódik benne, hogy nem tudja ellátni gondozói feladatait (Pulay, 2003).

A család szerepe sem hanyagolható el a kötődés minőségét meghatározó tényezők sorában. Az alacsony társadalmi-gazdasági helyzet feszültségkeltő hatást válhatnak ki a szülökben, ezzel csökkentve a biztonságos kötődés valószínűségét. Fontos tényezőként számon tartani a családi viszályokat. Azoknak a pároknak a gyermekei, akik problémákkal küzdenek, nagyobb valószínüséggel lesznek bizonytalanul kötődőek. A családi gondok csökkenthetik a szülői érzékenységet, másfelöl pedig, ha a gyerek tanúja a házastársak közötti állandó és folyamatos torzsalkodásnak, számára a szülők nem lesznek a kényelem és a biztonság forrásai (Cole, 2006).

A gyerekek és gondozók közötti kötődési mintázatokat az adott kultúrára jellemző sajátosságok is meghatározhatják. Nagyon kevés biztonságosan kötődő gyermeket figyeltek meg például az északnémet területeken. A vizsgálat végén kiderült, hogy a német szülők olyan kulturális értékeket képviselnek, amelyek viszonylag nagy távolságtartást követelnek meg a személyek között. Úgy gondolják, hogy a csecsemőket le kell szoktatni a testi érintésről, mihelyst maguk is képesek a közlekedésre (Cole, 2006).

Bereczkei Tamás munkatársaival magyarországi roma és nem roma gyerekeket vizsgált, s azt a konklúziót sikerült kutatásukból levonni, hogy a roma gyerekek között több a szorongó-ambivalens kötődési típus, mint a nem roma gyerekek körében. A jelenség hátterében a cigányság társadalmi és gazdasági jellemzői és családi életük sajátságait sejtik. A romák általában folyton változó, bizonytalan, előre kiszámíthatatlan életkörülmények között élnek, s ennek következtében a mindennapjaik is épp ilyen változóak. A kutatók azt feltételezik, hogy emiatt, illetve a magas gyermekhalandóság miatt a roma anyák, kevesebbet invesztálnak gyermekeikbe, ennek hatására nagyobb arányban válnak szorongóvá, bizonytalanná a kötődésükben a gyerekek. Folyton az anya hangulatingadozásait kell figyelniük, s mivel ő gyakran nem elérhető érzelmileg, ezért a gyerekek erőfeszítésük növelésével még szorosabb kötődést igyekeznek kialakítani, így alakul ki a szorongó-ambivalens kötődési típus. Ezeknek az adatoknak az arányai azonban korántsem olyan mértéküek, hogy följogosítsanak arra, hogy bármiféle egységes roma nevelési stílusról tehessek megállapítást (Bereczkei, 2001 idézi F. Lassú, 2011).

Nincs még közös megegyezés azzal kapcsolatban, hogy mennyire fontosak és mérvadóak a kötődési minták, különféle kultúrákat jellemző elosztásban. Egyesek szerint jelentős különbségeket tükröznek, míg mások úgy gondolják, hogy a kulturális téren tapasztalt különbségek téves következtetésre adnak okot és elterelik a vizsgálat figyelmét arról, hogy az érzelmi kötelék igazi természetére lehessen következtetni. A jelenlegi kutatások egyértelműen rámutatnak az idegen helyzetben produkált kulturális különbségekre, ezek pszichológiai jelentősége azonban a mai napig még bizonytalan (Cole, 2006).

\section{Kötődés iskolás- és serdülőkorban}

A vizsgálatban résztvevő gyerekek iskolás- és serdülökorúak, így elengedhetetlen áttekinteni a kötődésnek erre az életkori szakaszra jellemző motívumait.

A hetedik életévben a társkapcsolatok fejlődésében jelentős fordulat áll be. $A$ kötődések tendenciája megváltozik. A társas érdeklődés a felnőttekről a kortársakra 
tevődik át fokozatosan. Ezt a változást átpártolásnak nevezzük. Az átpártolásnak mint folyamatnak az a lényege, hogy a kétféle kapcsolat - gyermek-felnőtt, illetve gyermek-gyermek - indulati szintkülönbsége között kezdetét veszi a kiegyenlítődés. Az egyiknek csökken, míg a másiknak megnövekszik az érzelmi hőfoka. Megnövekszik a kortársakkal történő időtöltés igénye (Mérei és V. Binét,1970).

A kortárskapcsolatok prioritása iskoláskorban kezdődik meg és serdülőkorban éri el tetőpontját. Ekkor központi szerepet kap a serdülő gyermek számára a szülőről való érzelmi leválás is, ami előkészíti a fizikai leválást is (Bíró, 2011).

A prepubertás és pubertás korra alapvetően jellemző az autonómia igénye, az identitás keresése. A kortárs kapcsolatok jelentősége felértékelődik ebben a korban, míg a szülőkkel való kapcsolat jelentéktelenebbé válik, gyakran akár terhes is lehet.

\section{Az empirikus vizsgálat jellemzői}

\section{Célok és hipotézisek}

A kutatás célja a magas rizikófaktorú deviáns-veszélyeztetett, illetve a nem veszélyeztetett fiatalok anyai kötődésének erőssége közötti azonosságok, illetve különbözőségek feltárása volt. A kutatást megelőzően az alábbi két kardinális hipotézis fogalmazódott meg a témával kapcsolatban.

1. A vizsgálati csoport és a kontrollcsoport között jelentős eltérés mutatható ki a deviáns-veszélyeztetettség szempontjából.

2. A vizsgálati csoport, illetve a kontrollcsoport anyai kötődési erőssége között lényeges eltérés mutatható ki.

\section{A kutatási minta bemutatása}

A vizsgálati csoport tagjai összesen 54-en vannak, ebből 32 fiú és 22 lány. A legidősebb tanulók - a kérdőív kitöltésekor - 15 évesek, összesen négyen vannak. A legfiatalabbak 11 évesek, összesen három ilyen tanuló van. Az édesanya iskolai végzettségét tekintve a vizsgálati csoportban résztvevő 54 gyerek közül, 53 tanuló édesanyjának legmagasabb végzettsége, legfeljebb 8 általános. Egy tanuló esetében az anya legmagasabb iskolai végzettsége középfokú szakképzettség.

A kontrollcsoportban résztvevő tanulók összesen 40-en vannak, ebből 15 fiú és 25 lány. A legidősebbek, a kérdőív kitöltésekor, 14 évesek, ők tizenketten vannak. A legfiatalabb tanuló 12 éves. 6 tanulónál az édesanya legmagasabb iskolai végzettsége az érettségi, míg 16 tanuló esetében a főiskolai diploma, szintén 16 tanuló esetében pedig egyetemi diploma. Az adott kérdéskörben két hiányzó adat van.

\begin{tabular}{|l|c|c|c|}
\hline \multicolumn{1}{|c|}{ Nem } & Kontrollcsoport & Vizsgálati csoport & Összesen \\
\hline Fiú & 15 & 32 & 47 \\
\hline Lány & 25 & 22 & 47 \\
\hline Összesen & 40 & 54 & 94 \\
\hline
\end{tabular}

1. táblázat: A kutatásban részt vevők száma nemek szerinti bontásban

\section{A kutatás módszere}

A kutatást kérdőíves módszerrel végeztem, két kérdőívet használtam föl. Az első, az eredetileg Popper, Hegedűs, Feuer, Lajti és Glauber (1988) által létrehozott deviánsveszélyeztetettség prognosztikai skálájának Szitó Imre (1991) által módosított változata. 
Az anyai kötődés feltárásához az Armsden és Greenberg (1987) által kidolgozott Inventory of Parent and Peer Attachment (IPPA) önbeszámolós kérdőívet alkalmaztam.

A kérdőívek jellegzetességeiből adódóan a kapott eredmények kvantitatívak, vagyis számszerüsíthetőek, tehát lehetőséget kínálnak az adatok statisztikai elemzésére.

Az IPPA esetében Likert típusú skálán volt lehetőségük a kitöltőknek az itemek megválaszolására, az öt választó kategória helyett azonban négy választó kategóriát alkalmaztam, a „szinte soha nem igaz” és a „szinte mindig igaz” közti tartományokból kellett a válaszadóknak számokat megjelölniük egytől négyig. A páros számú kategória használatával a semleges fokozat elkerülése volt a célom.

A kutatást egy-egy adott intézmény felső tagozatos tanulóin végeztem el, a kiválasztás tehát leginkább önkényes mintavételnek tekinthető, ezért a teljes sokaságra nézve a vizsgálati eredmények nem reprezentatívak.

\section{Eszközök bemutatása}

\section{A prognosztikai skála bemutatása}

A deviáns veszélyeztetettség feltárására a Szitó Imre (1991) által módosított prognosztikai skálát használtam. A prognosztikai skála egy igen komplex mérőeszköz. Négy nagy faktort különböztet meg, melyek a háttér- és közvetlen faktorok, a megfigyelhetö személyiségvonások, illetve a predeviáns tünetek. A faktorok különböző alfaktorokra bonthatóak, melyek további itemekre tagolódnak, az itemekhez pedig különböző nyerspontértékek járulnak. A végleges pontértékek megállapítása alapján a prognózis hat kategória valamelyike lehet, mely kategóriák az alábbiak: „iskolai beavatkozást igénylő veszélyeztetettség”, „szakvizsgálat indokolt”, „deviáns tendenciák”, „deviáns veszélyeztetettség”, „súlyos deviáns veszélyeztetettség”, illetve a "nem igényel beavatkozást" mint hatodik kategória.

\section{Az Inventory of Parent and Peer Attachment kérdőív bemutatása}

A kérdőív eredetileg három területet mér föl: az anyához, az apához, illetve a barátokhoz füződő viszonyt. Jelen esetben az édesanyával kapcsolatos viszony áll a mérés középpontjában.

A kérdőív eredetileg ötfokú Likert-skálát használ, a „szinte soha nem igaz” és a „szinte mindig igaz” választó kategóriákkal.

A teszt alapvetően a serdülők kötődésének három aspektusát méri. A bizalom a kölcsönös megértés fokát méri, pl.: „Anyukám elfogad engem olyannak, amilyen vagyok." A kommunikáció faktor a szóbeli kommunikáció minőségét és mértékét határozza meg, pl.: „Meg tudom beszélni anyukámmal, ha valami feldühít.” Míg végül az elidegenedés mint kérdéskör a harag érzéseit és az interperszonális elidegenedést méri, pl.: „Anyukám nem érti, hogy min megyek keresztül mostanában.” A kötődés a fönt említett három alskálából épül föl: a bizalom és a kommunikáció pontszámaihoz az elidegenedés fordított pontjait adva kapjuk meg a kötődés mértékét. Minél magasabb értéket kapunk, a kötődés annál biztonságosabbnak tekinthető. Az elidegenedés faktor negatívan korrelál a bizalom és a kommunikáció faktorral, így az elidegenedésre adott magas pontszám a bizonytalan kötődésre enged következtetni. A kérdőív biztonságérzet alapján végzi a besorolást, ezért viszonylag egyszerüen határozható meg a gyermek kötődése biztonságos-e vagy sem (Bíró, 2011). A vizsgálat alapvető célja azonban nem a biztonságosság perspektívájából vizsgálni az anyához való kötődést, hanem a kapcsolat erősségének feltárása. 


\section{A kutatás menete}

A vizsgálat 2014 novemberétől 2015 januárjáig tartott. A vizsgálati csoport tagjai egy dél-hevesi kistelepülés általános iskolájának felső tagozatos tanulói. A település része Heves megye leghátrányosabb régiójának. A falu lakóinak száma 1526 fő. A gyermekkorúak aránya igen magas, a Központi Statisztikai Hivatal adatai szerint 444 a 0-17 évesek száma a faluban. A munkanélküliek, illetve az inaktív keresők száma a községben megközelíti az 50 százalékot (KSH, 2014).

Az iskola, ahol a vizsgálat zajlott, egy állami fenntartású intézmény, ahová közel 120 gyermek jár. (A településen az állami iskolán kívül található még egy egyház által müködtetett általános iskola is.) A tanulók kivétel nélkül hátrányos helyzetűek, de igen magas a halmozottan hátrányos helyzetű gyerekek aránya is.

A kontrollcsoport tagjai ezzel szemben nem faluban élő, hanem városi diákok voltak. A megyeszékhely egyik neves általános iskolájának, találomra kiválasztott felsős tanulói vettek részt a vizsgálatban.

A kitöltött kérdőívek adatait táblázatba rendeztem és az IBM SPSS Statistics 22 program segítségével elemeztem az értékeket.

\section{A vizsgálat eredményei}

\section{Különbségek a deviáns veszélyeztetettség tükrében}

Azt feltételeztem, hogy a két csoport között nagyarányú eltérés mutatható ki a deviáns-veszélyeztetettséget illetően.

A hipotézisemet egyfelöl saját tapasztalataimra alapoztam, másrészt pedig fölvettem a kapcsolatot a helyi szociális és gyermekjóléti intézménnyel, akikhez a vizsgálati csoport tagjai hivatalosan tartoznak. A jelzőrendszer által küldött jelzések száma nagyon magas volt a 2014-es évben is. A legtöbb jelzés a közoktatási intézményből érkezett, de a rendőrség, az egészségügyi szolgáltató, illetve az önkormányzat, jegyző és a gyámhivatal részéről is igen nagy számban érkezett bejelentés a szakszolgálathoz.

Továbbá a hipotézisem kialakításához nagymértékben hozzájárult a vizsgálati csoport településén kialakult helyi sajátosságok fölfedezése, családi tradíciókkal, életkörülményekkel való megismerkedés. A deviancia Andorka és Harcsa (1990) szerinti értelmezését alapul véve a településen igen magas a deviáns csoportok száma. A családsegítő szakemberek elmondása szerint rendkívül gyakori a bünözés, - leginkább lopás, rablás jellemző - illetve magas az alkoholisták aránya is, korra és nemre való tekintet nélkül. A mentális sérülékenység a gyermeket nevelő szülők körében, a helyi családsegítő szakemberek visszajelzései alapján, magas arányban van jelen. Mivel a devianciát szocio-genetikus transzmisszióként értelmezzük, ezért is feltételeztem, hogy a fönt részletesen bemutatott szülői minta hatással van a gyermek viselkedésére, illetve konkrétan növeli a veszélyeztetettségi esélyeit.

A deviáns veszélyeztetettség prognosztikai skáláját az osztályfőnökök segítségével készítettem el. Mivel a skála kérdéseinek túlnyomó többsége tényeken, nem tapasztalatokon alapszik, pl.: „Egyik szülő börtönben”, „Újraházasodás”, „Évismétlő, túlkoros", így az osztályfőnök mint legilletékesebb pedagógus válaszai, hiteles adatnak tekinthetők. Az eredmények a 2. táblázatban láthatóak. 
A deviáns veszélyeztetettség és az anyai kötődés kapcsolata

\begin{tabular}{|l|c|c|c|}
\hline \multicolumn{1}{|c|}{ Kategória } & Kontrollcsoport & $\begin{array}{c}\text { Vizsgálati } \\
\text { csoport }\end{array}$ & Összesen \\
\hline Nem igényel beavatkozást & 40 & 1 & 41 \\
\hline Iskolai beavatkozást igénylő & 0 & 22 & 22 \\
\hline Szakvizsgálat indokolt & 0 & 19 & 19 \\
\hline Deviáns tendenciák & 0 & 8 & 8 \\
\hline Deviáns veszélyeztetettség & 0 & 4 & 4 \\
\hline Súlyos deviáns veszélyeztetettség & 0 & 0 & 0 \\
\hline Hiányzó adat & 0 & 0 & 0 \\
\hline Összesen & 40 & 54 & 94 \\
\hline
\end{tabular}

2. táblázat: A kutatásban részt vevők eloszlása deviáns veszélyeztetettség alapján

A kontrollcsoportban résztvevő tanulók közül egyetlen gyermek sem igényel semmilyen jellegü beavatkozást.

A vizsgálati csoportot illetően a helyzet egy kicsit differenciáltabb. Itt, az 54 tanuló közül egyetlen van, aki nem igényel beavatkozást, tehát minimális mértékben sem tekinthető deviáns-veszélyeztetettnek.

A legtöbb tanuló a második veszélyeztetettségi faktorba került, tehát iskolai beavatkozást igényelnek. A tanulók jelentős hányadánál szakvizsgálat indokolt, de igen magas a deviáns tendenciákat mutatók száma is. A súlyos deviáns veszélyeztetettség kategóriába nem került senki a vizsgálati csoport gyermekei közül, a deviáns veszélyeztetettség faktorba azonban négy tanuló is.

Ahogy már föntebb említettem, az osztályfőnökökkel készített interjúk alapján sikerült a prognosztikai skála értékeit megállapítani. A kérdőív alapvetően nem önbevalláson alapszik, hanem a pedagógus a tények és tapasztalatok alapján nyilatkozik a tanulókról. Így a gyerekeknek nem kellett jelen lenniük ahhoz, hogy a prognosztikai skála hiánytalanul elkészüljön mindenkiröl. Ennek köszönhetően a tesztet minden gyerekröl fölvettem, így a prognosztikai skálát illetően nem beszélhetünk hiányzó tanulókról. A másik kérdőív kitöltésénél azonban több tanuló sem volt jelen. Az adatok elemzésénél így egy újabb ismérv alapján lehet csoportosítani a kitöltőket „,hiányzó” és „nem hiányzó” csoportra. Az adott ismérv alapján jelentős különbség mutatkozik a vizsgálati csoport tagjainál.

\begin{tabular}{|l|c|c|c|c|c|}
\hline & Hiányzó & Nem hiányzó & Fiú & Lány & Összesen \\
\hline Előfordulás & 7 & 47 & 32 & 22 & 54 \\
\hline Átlag & 205,57 & 83,79 & 115,16 & 76,91 & 99,57 \\
\hline Szórás & 76,67 & 56,81 & 81,05 & 49,46 & 71,91 \\
\hline Minimum & 69 & 4 & 4 & 28 & 4 \\
\hline Maximum & 295 & 239 & 295 & 218 & 295 \\
\hline
\end{tabular}

3. táblázat: Deviáns-veszélyeztetettségi pontszámok hiányzás és nemek szerinti bontásban a vizsgálati csoportban

Az 3. táblázatból láthatjuk, hogy a nem hiányzó tanulók átlagos pontszáma 84 , míg a hiányzóké ennek több mint a duplája, 206 pont. A hiányzó tanulók értékei nagyobb mértékben szóródnak, mint a nem hiányzóké.

A fiúk értékeinek szórása nagyobb, mint a lányoké, tehát a fiúkkal kapcsolatos eredmények nagyobb változatosságot mutatnak.

A hiányzás és nem hiányzás mellett a fiúk és a lányok válaszainak különbözőségét is szemlélteti az alábbi boxplot ábra (1. ábra). 


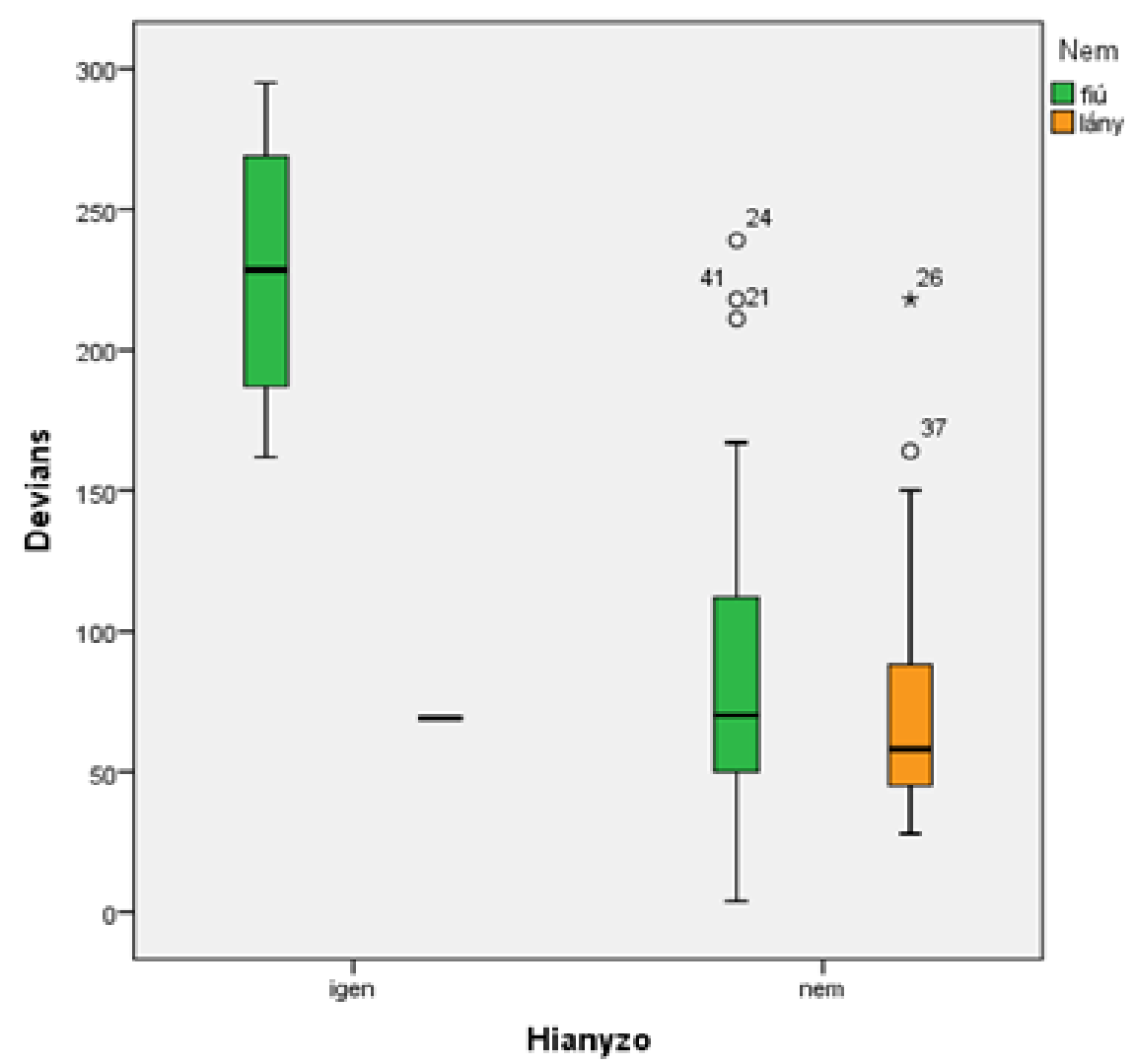

1. ábra: Deviáns-veszélyeztetettségi pontszámok eloszlása hiányzás és nemek szerint a vizsgálati csoportban (IBM SPSS Statistics 22)

A nem hiányzó fiúknál igen magas értékű és viszonylag sok a kiugró esetek száma, mely pontértékek mind a harmadik és negyedik veszélyeztetettségi kategóriába tartoznak. A lányok esetében (nem hiányzók) egy kiugró értékről és egy extrém értékről beszélhetünk. A nem hiányzó lányok és a nem hiányzó fiúk pontértékeinek mediánja közel azonos.

Alapvetően a hiányzó fiúk magas rizikófaktorúak a deviáns veszélyeztetettség szempontjából. Az eredmény azért sem meglepő, mert a prognosztikai skála közvetlen faktorok csoportjában szerepel a rendszeresen igazolatlanul hiányzik item, amely a hiányzó fiúk esetében a kitöltött teszt alapján is releváns, illetve az utolsó faktor a predeviáns tünetek egyik iteme az aluljárókban, tereken, bevásárlóközpontokban lődörgés, amely szintén releváns a hiányzó fiú tanulóknál. Az iskolából való notórius, napokig akár hetekig való hiányzás tehát, a deviancia egyik megjelenési formája az iskolai normák dimenziójában.

A deviáns veszélyeztetettséget mérő prognosztikai skála adatait összesítve azt állapíthatjuk meg, hogy a vizsgálati csoportban a hiányzó fiúk érték el a legmagasabb értéket, maguk mögé utasítva ezzel - sorrendben - a nem hiányzó fiúkat, a nem hiányzó lányokat és a hiányzó lányt.

A táblázatok és ábrák adatainak összegzése után, a vizsgálati csoportot illetően azt a konzekvenciát szürhetjük le, hogy a fiúk pontértékei magasabbak a deviáns veszélyeztetettséget mérő prognosztikai skálán, mint a lányok eredményei. Tehát a fiúk - deviancia szempontjából - veszélyeztetettebbek a lányoknál. Más empirikus kutatások eredményei is bizonyítják ezt a megfigyelést, hogy a férfiak esetében gyakoribb a deviáns viselkedésforma megjelenése. Többek között az alkoholfogyasztást mint devi- 
A deviáns veszélyeztetettség és az anyai kötődés kapcsolata

áns viselkedésformát illetően, a Központi Statisztikai Hivatal adatai alapján, 2013-ban háromszor annyi regisztrált alkoholista volt a férfiak körében Magyarországon, mint a nőknél (KSH, 2013).

A prognosztikai skála kiértékelése után elmondhatom, hogy a vizsgálati csoportban résztvevő gyerekek 98 százaléka a deviáns-veszélyeztetett kategóriába tartozik, s ebből kifolyólag valamilyen beavatkozást igényel.

A kontrollcsoportot illetően az osztályfőnöki interjúk során az derült ki, hogy a tanulók jelentős többségére egyáltalán nem jellemzőek a prognosztikai skála faktorai és itemei. Így a kontrollcsoport nagy hányada mindössze nulla pontot ért el a skálán. Voltak természetesen, akik szereztek pontot. A legtöbbet a közvetlen faktorok csoportból gyűjtötték a tanulók, illetve a háttérfaktorok kategóriában is volt néhány jellemző item, mint például a válás vagy a túlvédő, túlféltő vagy a túlkövetelő család. Amit azonban fontos leszögezni, hogy a kontrollcsoport tagjai közül egyetlen gyermek sem érte el a 15 pontot, tehát tulajdonképpen senki nem szorul semmilyen jellegű beavatkozásra, vagyis senki sem mutat minimális mértékü deviáns-veszélyeztetettséget sem. A két csoport közötti különbség tehát jelentős, a vizsgálati csoport tagjai nagyobb arányban mutatnak deviáns-veszélyeztetettségre utaló jeleket, mint a kontrollcsoport tagjai, a hipotézisem tehát elfogadottnak tekinthető.

Nem szabad azonban figyelmen kívül hagynunk a kultúrák közötti alapvető különbségek tényét, és azt sem, hogy szabályrendszereiket is a különféle csoportok saját maguk határozzák meg. Azon a településen, ahol a vizsgálati csoport tagjai élnek, a lakosság jelentős hányada azonos értékek szerint él, melyet igyekeznek átörökíteni gyermekeikre is. Ezek a szabályok, értékek ugyan különböznek a mai általános, európai társadalmi normáktól, ám abban a mikroközösségben pont az minősül kívülállónak, aki nem igazodik ehhez az életvitelhez, ezekhez a normákhoz. Tehát, hogy mennyire számít deviáns viselkedésnek egy adott közösségben az alkohol- vagy drogfogyasztás? Amennyire az adott közeg ezt normaszegésnek minősíti. Az adott településen a gyerekek iskolában tanúsított viselkedését sem a szülő, sem a gyermek nem érzi a normától való eltérésnek. A pedagógus az, aki ezt devianciának stigmázza. Abban az adott közegben a gyermeknek akkor magasabbak az esélyei, - minden tekintetben - ha követi a sztenderd viselkedést, életvitelt. Amennyiben szeretne kitörni az adott közegből, úgy nyilván az új, más csoportokra jellemző szabályokat is adaptálnia kell.

Tehát a két csoport között valóban különbség van. Ha a vizsgálati csoport egyik tagját illesztenénk be a kontrollcsoportba, akkor valószínủleg deviánsnak számítana, ám ha a kontrollcsoport egyik tagját helyeznénk a vizsgálati csoportba, úgy, - a deviancia fenti értelmezése alapján - valószínűleg ő is deviánsnak számítana, hiszen a vizsgálati csoport által meghatározott normától eltérő viselkedés jellemzi.

Összességében az a konzekvencia szürhető le, hogy a társadalom által meghatározott normák aspektusából valóban deviáns-veszélyeztetett a vizsgálati csoport gyerekeinek jelentős hányada, azonban a saját közegükben nem minősülnének ekkora számban és mértékben eltérőnek, tehát deviánsnak.

\section{Az anyához való kötődés}

Azt feltételeztem, hogy a két csoport anyai kötődési erőssége között jelentős eltérés mutatható ki.

Alapvetően azt gondoltam, hogy a deviáns-veszélyeztetett gyerekek kevésbé szoros kötődést fognak mutatni az édesanyjuk irányába, mint a nem veszélyeztetettek. A hipotézisemet az ártalmas környezeti tényezők halmozódására alapoztam. Egy-egy környezeti tényező negatív hatással ritkán van a kötődésre, a halmozódása 
azonban már negatívan hat a kapcsolatokra. Magas rizikójú csoportok esetében találtak kapcsolatot a környezet és kötődés között (Kósáné és Mirnics, 2007 idézi Bíró, 2011). A biztonságos kötődés kialakulását sok összetevő befolyásolja. A környezeti tényezők közül a demográfiai tényezők, a jövedelem, a testvérek száma, az iskolázottság, szülők mentális sérülékenysége, a szenvedélybetegségek és a transzgenerációs hatások (Bíró, 2011).

A vizsgálati csoport tagjainak esetében általánosságban rendkívül magas testvérszámról, - nem ritka a 10-12 testvér sem - kiugróan alacsony jövedelemről, igen alacsony iskolázottságról - a megszokott a nyolc általános vagy annál alacsonyabb végzettség - és a szenvedélybetegség - gyakran nemcsak az alkohol, hanem a manapság rendkívül divatos olcsó, dizájnerdrogok használata - jelenlétéről van szó. Ezek a faktorok együttes jelenléte már halmozódásnak minősül, ami megalapozta a feltételezésemet.

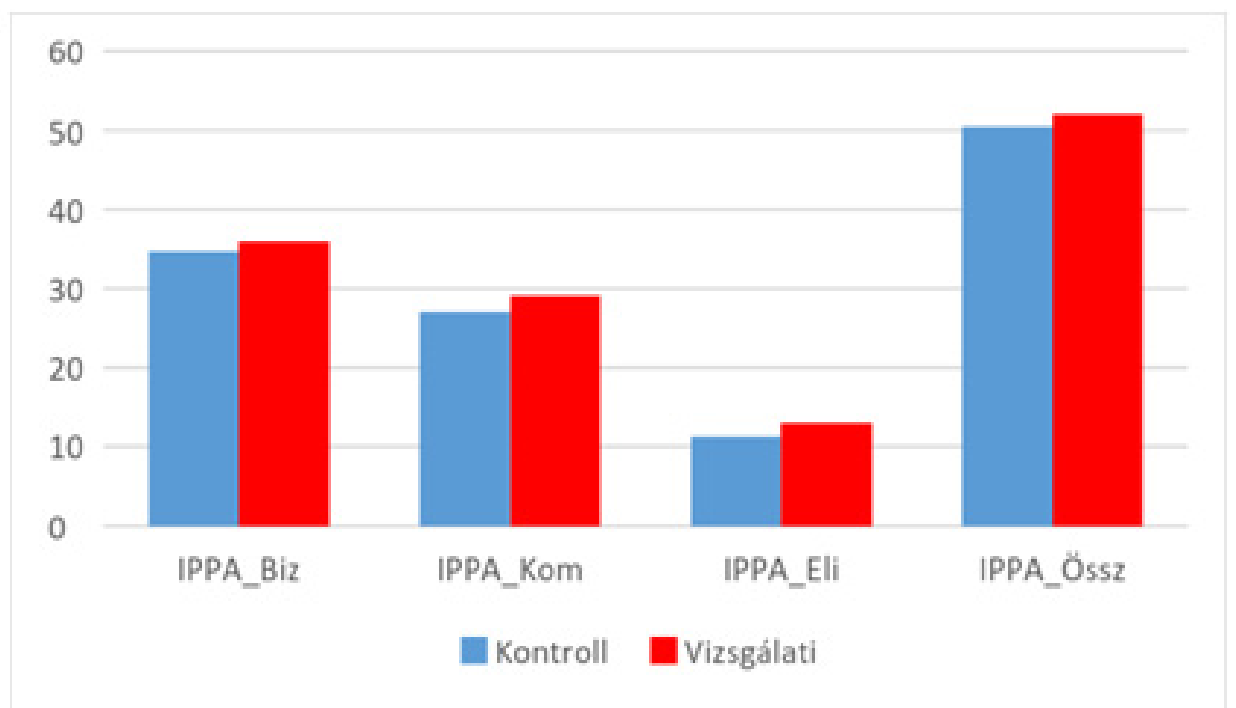

2. ábra: IPPA-pontszámok átlaga csoportonként, faktoronkénti bontásban (IBM SPSS Statistics 22)

Ahogyan az ábrán látható (2. ábra), az összes kérdésre adott pontszámok átlaga a vizsgálati csoportnál 52,09 míg a kontrollcsoportnál 50,48. A mintaátlagok összehasonlításhoz kétmintás t-próbát alkalmaztam. 95\%-os szingifikanciaszinten a t-eloszlás küszöbértéke 85-ös szabadságfok mellett 1,99. A t-próba értéke a teljes IPPA-esetében 0,68, tehát 95\%-os megbízhatósági szinten az átlagok eltérése nem bizonyított $\left(\mathrm{t}_{\text {számított }}<\mathrm{t}_{\text {student }}\right)$.

Az összesített pontértékek szórásánál viszont jelentős különbség mutatható ki. $A$ vizsgálati csoport adott pontszámainak szórása 8 , a kontrollcsoportnál a szórás értéke viszont 14, majdnem a duplája a vizsgálati csoporténak. Ezt az eltérést a Varianciaanalízisben használt F-próbával hitelesítettem. A teszt alapján tehát a teljes IPPA-nál mutatkozó szórásbeli különbség szignifikáns eltérést mutat.

\section{Az eredmények megvitatása}

Az Inventory of Parent and Peer Attachment kérdőív elemzése után azt állapíthatjuk meg, hogy a két csoport válaszai alapján létrejött eredmények között nem mutatható ki jelentős különbség. Vannak faktorok, melyek nagyobb eltérést mutatnak, illetve a szórást, a válaszok tartományát illetően is találhatunk eltéréseket, de összességében 
nem szignifikáns különbségekröl van szó. Egyéni eltérések nyilván megjelennek, de az összesített eredményt nem befolyásolják olyan jelentős mértékben, hogy egyértelmű különbséget lehetne tenni a kontroll és vizsgálati csoport között.

$A z$, hogy a környezeti faktorok ilyen nagymértékü halmozódása ellenére is ilyen eredmények jöjjenek létre, elgondolkodtató.

Egyfelől megközelíthető abból az aspektusból, amit Bowlby hangsúlyozott, miszerint a ragaszkodó magatartásformák nem külső megerősítők hatására jönnek létre, hanem belsőleg motiváltak, ami azt jelenti, hogy a gyerekek akkor is kötődhetnek a gondozóhoz, ha az nem elégíti ki igényeiket. A gyerekek képesek bántalmazó szülöhöz is kötődni, ez arra szolgál bizonyítékul, hogy a ragaszkodó magatartásrendszert nemcsak a pozitív tapasztalatok formálják (F. Lassú, 2011).

A teszt differenciálatlansága miatt nincs lehetőség arra, hogy különbséget tegyek az értékelés folyamán a valódi és a vágyott kapcsolat között. A gyerekek válaszai alapján az is elképzelhető opciónak tünik, hogy egy olyan kapcsolatrendszert jelenítettek meg, amire vágynak, amit szeretnének, amit optimálisnak tartanak, miközben a valóságban megtapasztalt kapcsolatrendszerük ettől eltérő.

A kutatás alapvető hipotézise tehát az volt, hogy a deviáns-veszélyeztetett és a nem veszélyeztetett fiatalok anyai kötődésük erősségének függvényében eltérést mutatnak. A kérdőívek eredményeit elemezve azonban ez a feltételezés nem bizonyítható, hiszen a két csoport között nem mutatható ki releváns különbség az adott kérdést illetően. Tehát a felvetés, hogy a deviáns veszélyeztetettség hatással lehet-e az anyához való kötődés erősségére, az adott válaszok alapján nem igazolható.

A vizsgálat továbbfejleszthető és az eredmények pontosíthatóak, amennyiben a prognosztikai skála környezeti faktorokra, illetve a megfigyelhető személyiségvonásokra fókuszáló kérdésköreinél másodvélemény is felvételre kerül. A védőnő, illetve a gyermekorvos válaszai olyan részleteket is föltárhatnak, ami alapján pontosabb kép kapható a gyerekek veszélyeztetettségét illetően. A kutatás a kötődés aspektusából is kiterjeszthető. Az erősségméréshez használt kérdőív helyett az interjú technika alkalmazása adhat egzaktabb képet a válaszadók kötődésminőségét illetően.

\section{Irodalom}

Andorka Rudolf és Harcsa István (1990): Deviáns viselkedés. In: Andorka Rudolf, Kolosi Tamás és Vukovich György (szerk.) Társadalmi riport. TÁRKI, Budapest, 217-227.

Atkinson, R. C. és Hilgard, E. (2006): Pszichológia. Osiris Kiadó, Budapest.

Armsden, G. C. és Greenberg, M. T. (1987): The Inventory of Parent and Peer Attachment: Individual Differences and Their Relationship to Psychological Well Being in Adolescence. Journal of Youth and Adolescence, 16. 427-454.

Bíró Violetta (2010): Magas rizikófaktorú serdülők kötödésének és coping mechanizmusainak összefüggései internalizációs és externalizációs problémáival. Doktori (PH.D.) értekezés, Pécs. URL: http://pszichologia.pte.hu/sites/pszichologia.pte.hu/files/files/files/dok/disszert/d2011-biro_violetta.pdf (letöltve: 2015.04.11. 12:23)

Bowlby, J (2009): A biztos bázis. Animula Kiadó, Budapest.

Cole, M. és Cole, S. R. (2006): Fejlődéslélektan. Osiris Kiadó, Budapest.

F. Lassú Zsuzsa (2011): Kötődés és változatai a szülő mentális sérülékenységének kontextusában. In: F. Lassú Zsuzsa (szerk.) Gyermekek mentálisan sérülékeny családokban. ELTE Eötvös Kiadó, Budapest. 51-75.

Láng András (2012): Kötődés és pszichoterápiás kapcsolat. Animula Kiadó, Budapest.

Kisida Erzsébet (1999): A fiatalkorúak veszélyeztetettsége. Új Pedagógiai Szemle. 4. 12-17.

Main M. és Solomon J. (1990): Procedures for identifying infants as disorganised/disoriented during the Ainsworth Strange Situation. In: M.T. Greenberg, D. Cicchetti and E.M. Cummings (eds.) Attachment in the Preschool Years. University of Chicago Press, Chicago. 121-160. 
Main M. és Hesse E. (1990). Parents' unresolved traumatic experiences are related to infant disorganised attachment status. M.T. Greenberg, D. Cicchetti and E. M. Cummings (eds.) Attachment in the Preschool Years. University of Chicago Press, Chicago. 121-160.

Mérei Ferenc és V. Binét Ágnes (1970): Gyermeklélektan. Gondolat Kiadó, Budapest.

Pikó Bettina (2011): A deviáns magatartás értelmezési keretei a biopszichoszociális elmélet tükrében. In: Pikó Bettina (szerk.) A deviáns magatartás szociológiai alapjai és megjelenési formái a modern társadalomban. JATE Press, Szeged. 9-16.

Popper Péter, Hegedús T. András, Feuer Mária, Lajti Rudolf és Glauber Anna (1988): Beilleszkedési zavarok korai felismerése gyermek- és serdülőkorban. In: Illyés Sándor (szerk.) Veszélyeztetettség és iskola. Tankönyvkiadó, Budapest. 269-308.

Pulay Klára (2003): A kötődésről és az anya hiányáról. Ragaszkodás és kötődés. In: B. Lakatos Margit és Serföző Mónika (szerk.): Pszichológia szöveggyüjtemény óvodapedagógus hallgatóknak. Trezor Kiadó, Budapest. 101-118.

Szitó Imre (1991): A deviáns veszélyeztetettség prognosztikai skálája (módosított). URL: http://www.szitoimre.com/kerdoiv/veszely.pdf (letöltve: 2014.10.11.) 